\title{
PERFORMANCE EVALUATION OF EXISTING WASTE WATER TREATMENT PLANT
}

\author{
B.G.Mahendra ${ }^{1}$, Prema $^{2}$ \\ ${ }^{1}$ Associate Professor, Department of Civil Engineering, ${ }^{2}$ M.Tech Scholar, Department of Environmental Engineering, \\ PDA College Of Engineering, Gulbarga \\ bgm_pda@yahoo.co.in, prematengli52@gmail.com
}

\begin{abstract}
Dairy industry is one of the major industries causing water pollution. In India, dairy industry generates about 6-10 L of wastewater/L of milk processed, depending upon the process scheme and products manufactured. Poorly treated wastewater with high levels of pollutants caused by poor design, operation or maintenance of treatment systems creates major environmental problems, when such waste water is discharged to surface water or on land. Considering the above stated implications an attempt has been to evaluate the performance of wastewater treatment plant (WWTP) at KMF dairy, Gulbarga. Samples were collected from seven points; Raw waste water [P1] to Secondary clarifier [P6] including the treated effluent [P7] to evaluate the performance of WWTP. Parameters analyzed for evaluation of performance of WWTP are pH, Acidity, Alkalinity, COD, BOD 5 @ 20 $\mathrm{C}$, TS. Tests were performed to find the fate of pollutants in WWTP. The present study shows that COD removal efficiency of WWTP was found to be $49.89 \%$ and $B O D_{5}$ removal efficiency of WWTP was found to be 74.07\%. Though COD efficiency is high but its concentration in the treated effluent exceeds the limit prescribed by the regulatory authorities. Hence it is recommended to redesign the WWTP to achieve better performance.
\end{abstract}

Keywords: Waste water, performance, organic content, dairy industry. ****

\section{INTRODUCTION}

Rapid growth of industries has enhanced the productivity, but resulted in the production and release of polluting substances into the environment. Thus creating health hazards and effected normal life of flora and fauna. These wastes produce harmful effects on the environment and are generally released in the form of solids, liquid wastes and slurries containing organic and inorganic chemicals. Poorly treated wastewater with high levels of pollutants caused by poor design, operation or maintenance of treatment systems creates major environmental problems, when such waste water is discharged to surface water or land. Such problems includes Contamination and deoxygenation of streams and waterways by direct discharge or run off of inadequately treated wastewater, Excessive concentration of nutrients such as nitrogen and phosphorous in surface and subsurface water bodies. This contribute to excessive growth of plants and algae blooms, which makes the downstream water unsuitable for domestic, agriculture and industrial use, Land degradation and damage to pastures and crops. Long term damage to soil productivity due to excessive nutrient loading, High salinity, Low / High $\mathrm{pH}$, over application of wastewater to land resulting in contaminated ground water, Soil structure decline due to wastewater with high Sodium Adsorption Ratio, Clogging of soil by fats / solids from irrigated wastewater [5].

\subsection{General Description of KMF Milk Dairy}

\section{Gulbarga:}

The Present study is on "Performance evaluation of existing waste water Treatment Plant of Dairy Industry" i.e. KMF, Gulbarga, located at Gunj area, Humnabad road of Gulbarga City. It is around $8 \mathrm{~km}$ away from PDA College of Engineering, Gulbarga at the latitude $17^{\circ} 21^{\prime} 41^{\prime \prime} \mathrm{N}$ and longitude $76^{\circ} 50^{\prime} 56^{\prime \prime}$ Eand it was established in 1985AD. Since then it is producing processed milk, ghee, butter and other milk products. It has the milk processing capacity of 65,000 L/day and it produces waste water of around $25000 \mathrm{~L} /$ day. This waste water is being treated with the existing WWTP designed for an average flow of 50000 L/day. This industry has chilling centers at Hulsoorand Thana Kushoor with each of chilling capacity of 5 thousand liters per day (TLPD). Total chilling capacity 10 TLPD There is Bulk Milk Collars -15, Automatic Milk Collection-12 and Community Milking Parlours- 1 in the union The union procures on an average 0.56 lakh $\mathrm{kg}$ of milk/day and sales 0.61 lakh liters of milk/per day.

\subsection{Sources of Waste Water:}

In general, the wastes generated from milk based food industry are from the washing and cleaning the products remaining in the tanks, trucks, cans, pipings and other equipments is performed routinely after every processing 
cycle, Spillage is produced by leaks, overflow, freezing-on, boiling over, equipment malfunction or careless handling. Processing losses includes such as sludge discharge from clarifiers, evaporator entrainment, discharges from bottles and washers etc. Entrainment of lubricants from conveyors, stackers and other equipment appear in the waste water from cleaning operations. Routine cleaning of toilets, washrooms and facilities at the plant Non-dairy ingredients such as sugar, fruits, flavours, nuts and fruit juices used in manufacturing of certain products such as ice-cream, flavoured milk, frozen desserts and others.

\subsection{Objectives of the Study:}

The study was conducted at Environmental Engineering Laboratory, Department of Civil Engineering, PDA College of Engineering, Gulbarga with the following objectives.

- To identify the sources and quantify the waste water.

- To study the composition and characteristics of waste water.
- To study the performance of the existing waste water treatment plant and to suggest modifications ( if needed)

\section{MATERIALS AND METHODOLOGY}

\subsection{Wastewater Treatment Plant: An Overview of Existing WWTP:}

Waste water samples are collected from waste water treatment plant (WWTP) at different sampling points and characterized for parameters $\mathrm{pH}$, Solids, $\mathrm{BOD}_{5}, \mathrm{COD}$, Acidity, Alkalinity, chlorides, sulphate etc. An overview of WWTP and location of sampling points are as below:

- Effluent collection sump

- Equalization Tank

- Aeration Tank

- Primary Clarifier Tank

- Secondary Aeration Tank

- Secondary Clarifier Tank.

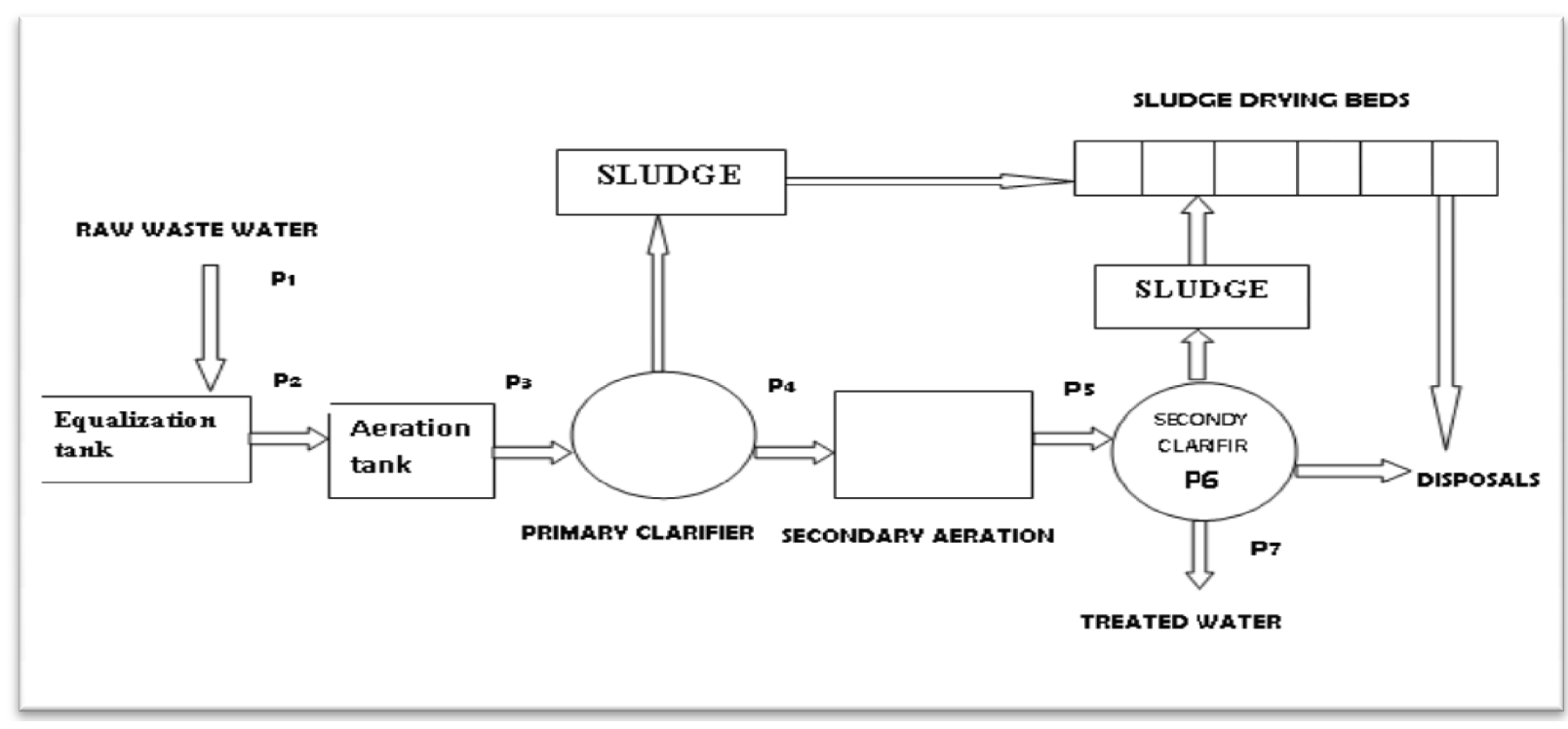

Figure 1: Flow diagram of Existing WWTP with sampling points

\subsection{Sampling Schedule and Frequency:}

Grab samples were collected once in a week from WWTP at the sampling points as shown in figure 1. Samples were collected weekly in plastic bottles and analyzed for the various parameters like $\mathrm{pH}$, Alkalinity, Acidity, $\mathrm{COD}, \mathrm{BOD}_{5}$ etc, as per the procedures laid down in Standard Methods for the examination of water and waste water(1979), $4^{\text {th }}$ edition were followed for samples collection, preservation and transportation [3].
Instruments And Methods Used [1,2]:Instruments and Methods used for analysing the above parameters are tabulated in Table 1. 
Table 1: Instruments used for measurement of different parameters

\begin{tabular}{|l|l|l|}
\hline Parameters & Unit & Instruments and Methods \\
\hline $\mathrm{pH}$ & --- & pH meter \\
\hline Alkalinity as $\mathrm{CaCO}_{3}$ & $\mathrm{mg} / \mathrm{l}$ & Titrimetric Method \\
\hline Acidity as $\mathrm{CaCo}_{3}$ & $\mathrm{mg} / \mathrm{l}$ & Titrimetric Method \\
& & \\
\hline Chloride as $\mathrm{Cl}$ & $\mathrm{mg} / \mathrm{l}$ & Titrimetric Method \\
\hline Solids & $\mathrm{mg} / \mathrm{l}$ & Hot air oven \\
\hline $\mathrm{BOD}_{5} @ 20^{\circ} \mathrm{c}$ & $\mathrm{mg} / \mathrm{l}$ & Winkler's Azide modification method \\
\hline $\mathrm{COD}$ & $\mathrm{mg} / \mathrm{l}$ & Open reflux method \\
\hline Sulphate as $\mathrm{SO}_{4}$ & $\mathrm{mg} / \mathrm{l}$ & Spectrophotometer \\
\hline
\end{tabular}

\section{RESULTS AND DISCUSSION}

3.1 Performance of WWTP:

The physico-chemical characteristics of raw waste water are given in Table 2. The key pollutants in the wastewater from milk industry are organic compounds and solids. Biodegradability may be estimated on the basis of ratio between $\mathrm{BOD}_{5} \& \mathrm{COD}$ ratio. This ratio ranges between 0.42 0.64 , which indicates the he part of the onganic compounds in the wastewater from milk industry is not easily degradable.
Total Solids in wastewater from WWTP was found to be 2880 $\mathrm{mg} / \mathrm{L}$ which includes the suspended solids originating from coagulated milk, cheese, curd or flavouring ingredients.

The use of acids, alkali, cleansers and sanitizers in the milk industry typically results in highly variable wastewater $\mathrm{pH}$ 7.88. The pHe value in this case varying between 6.45 to waste water contin high concentraion of organc watter, dissolved oxygen in waste water depletes because of the breakdown of organic matter, in absence of oxygen, sulphate e

Table 2: Characteristics of raw waste water from WWTP

\begin{tabular}{|c|c|c|c|c|c|c|c|c|c|c|c|c|c|}
\hline $\begin{array}{l}\text { Sam } \\
\text { plin } \\
\text { g } \\
\text { poin } \\
\text { ts } \\
\end{array}$ & $\begin{array}{l}\text { Col } \\
\text { or }\end{array}$ & pH & $\begin{array}{c}\text { Total } \\
\text { alkalinit }\end{array}$ & $\begin{array}{l}\text { Total } \\
\text { acidity }\end{array}$ & $\begin{array}{l}\text { Chlor } \\
\text { ides }\end{array}$ & $\begin{array}{l}\text { Total } \\
\text { solids }\end{array}$ & $\begin{array}{l}\text { Dissol } \\
\text { ved } \\
\text { solids }\end{array}$ & $\begin{array}{l}\text { Suspend } \\
\text { ed solids }\end{array}$ & $\begin{array}{l}\text { Total } \\
\text { volatil } \\
\text { e } \\
\text { solids }\end{array}$ & $\begin{array}{l}\text { BO } \\
D_{5} \\
@ \\
20^{0}\end{array}$ & COD & $\mathrm{SO}_{4}$ & $\begin{array}{l}\text { Amm } \\
\text { onical } \\
\text { nitrog } \\
\text { en }\end{array}$ \\
\hline P1 & Grey & $\begin{array}{l}6.4 \\
5\end{array}$ & 1019.50 & 0.0 & $\begin{array}{l}735.9 \\
0\end{array}$ & 2806.65 & $\begin{array}{l}1112.6 \\
5\end{array}$ & 1694.40 & 1466.0 & $\begin{array}{l}531 . \\
9\end{array}$ & $\begin{array}{l}1253 . \\
4\end{array}$ & $\begin{array}{l}763.0 \\
5\end{array}$ & 883.70 \\
\hline P2 & Grey & $\begin{array}{l}6.6 \\
5\end{array}$ & 925.33 & 0.0 & $\begin{array}{l}675.8 \\
0\end{array}$ & 2462.00 & 918.30 & 1543.70 & 1392.7 & $\begin{array}{l}460 . \\
5\end{array}$ & $\begin{array}{l}1067 . \\
0\end{array}$ & $\begin{array}{l}750.9 \\
1\end{array}$ & 797.72 \\
\hline P3 & $\begin{array}{l}\text { Light } \\
\text { Grey }\end{array}$ & $\begin{array}{l}7.3 \\
7\end{array}$ & 798.35 & 0.0 & $\begin{array}{l}606.5 \\
0\end{array}$ & 1956.35 & 816.80 & 1129.55 & 1248.9 & $\begin{array}{l}426 . \\
8\end{array}$ & $\begin{array}{l}865.4 \\
0\end{array}$ & $\begin{array}{l}611.8 \\
7\end{array}$ & 623.64 \\
\hline P4 & $\begin{array}{l}\text { Light } \\
\text { Grey }\end{array}$ & $\begin{array}{l}7.5 \\
9\end{array}$ & 721.80 & 69.7 & $\begin{array}{l}531.4 \\
0\end{array}$ & 1751.50 & 747.10 & 1006.40 & 1222.5 & $\begin{array}{l}346 . \\
9\end{array}$ & $\begin{array}{l}639.8 \\
0\end{array}$ & $\begin{array}{l}513.5 \\
6\end{array}$ & 413.67 \\
\hline P5 & Pink & $\begin{array}{l}7.6 \\
6\end{array}$ & 612.40 & 75.0 & $\begin{array}{l}452.1 \\
5\end{array}$ & 1647.15 & 672.15 & 975.00 & 1077.3 & $\begin{array}{l}351 . \\
8\end{array}$ & $\begin{array}{l}479.8 \\
0\end{array}$ & $\begin{array}{l}481.2 \\
7\end{array}$ & 320.37 \\
\hline P6 & Pink & $\begin{array}{l}7.7 \\
3\end{array}$ & 503.90 & 80.5 & $\begin{array}{l}373.0 \\
0\end{array}$ & 1480.50 & 581.00 & 898.20 & 872.50 & $\begin{array}{l}287 . \\
0\end{array}$ & $\begin{array}{l}361.5 \\
0\end{array}$ & $\begin{array}{l}435.5 \\
6\end{array}$ & 255.85 \\
\hline P7 & $\begin{array}{l}\text { Light } \\
\text { Pink }\end{array}$ & $\begin{array}{l}7.8 \\
8\end{array}$ & 412.65 & 92.3 & $\begin{array}{l}315.5 \\
0\end{array}$ & 1314.50 & 621.00 & 693.50 & 815.00 & $\begin{array}{l}210 . \\
0\end{array}$ & $\begin{array}{l}325.0 \\
0\end{array}$ & $\begin{array}{l}382.3 \\
5\end{array}$ & 129.68 \\
\hline
\end{tabular}

The performance of WWTP in terms of removal efficiency (\%) in the pollution parameters is given in Table 3 . 
Table 3: Removal efficiency of WWTP

\begin{tabular}{|l|l|l|l|l|}
\hline Parameters & Unit & $\begin{array}{l}\text { Efficiency of primary } \\
\text { settling tank }\end{array}$ & $\begin{array}{l}\text { Efficiency of secondary } \\
\text { treatment system }\end{array}$ & Overall efficiency \\
\hline $\mathrm{COD}$ & $\mathrm{mg} / \mathrm{l}$ & $26.06 \%$ & $49.20 \%$ & $49.89 \%$ \\
\hline $\mathrm{BOD}_{5} @ 20^{0} \mathrm{c}$ & $\mathrm{mg} / \mathrm{l}$ & $18.71 \%$ & $39.47 \%$ & $74.07 \%$ \\
\hline Total Solid & $\mathrm{mg} / \mathrm{l}$ & $10.47 \%$ & $24.95 \%$ & $53.16 \%$ \\
\hline Alkalinity $\left(\mathrm{as}_{\mathrm{CaCO}}\right)$ & $\mathrm{mg} / \mathrm{l}$ & $9.58 \%$ & $42.83 \%$ & $59.52 \%$ \\
\hline Sulphate as $\mathrm{SO}_{4}$ & $\mathrm{mg} / \mathrm{l}$ & $16.06 \%$ & $25.54 \%$ & $49.89 \%$ \\
\hline
\end{tabular}

\subsection{Use of Treated Waste Water for Irrigation:}

The Treated waste water is used for eco-plantation. Eucalyptus, Poplar, Teak and Jatropha. Nutrients present in the waste water are used by the plants and partially retained in the soil matrix without affecting the soil ecosystem.
Irrigation agriculture is dependent upon adequate good quality irrigation water. Treated effluent from WWTP and standards prescribed by the Karnataka State Pollution Control Board (KSPCB), Bangalore are listed in the Table 4.

Table4: Treated effluent value from WWTP against Standard value

\begin{tabular}{|l|l|l|l|l|}
\hline SI. No. & Parameters & Units & Treated Waste Water & Permissible Limit \\
\hline 1 & $\mathrm{pH}$ & ------- & 7.88 & $6.5-8.5$ \\
\hline 2 & Total solid & $\mathrm{mg} / \mathrm{L}$ & 1314.5 & 2200 \\
\hline 3 & Sulphate as $\mathrm{SO}_{4}$ & $\mathrm{mg} / \mathrm{L}$ & 129.68 & 1000 \\
\hline 4 & $\mathrm{COD}$ & $\mathrm{mg} / \mathrm{L}$ & 325 & 250 \\
\hline 5 & BOD $_{5} @ 20^{\circ} \mathrm{c}$ & $\mathrm{mg} / \mathrm{L}$ & 210 & 100 \\
\hline
\end{tabular}

(Source: Karnataka State Pollution Control Board, Bangalore)

\section{CONCLUSIONS}

Based on the Study, the following conclusions can be drawn.

1. The COD removal efficiency of WWTP was found to be $49.89 \%$.

2. The $\mathrm{BOD}_{5}$ removal efficiency of WWTP was found to be $74.07 \%$.

3. The Total solid removal efficiency of WWTP was found to be $53.16 \%$.

4. The current results suggest that the treated effluent is complying with the standard values and can be used for irrigation.

5. Though the efficiency of WWTP in respect of COD and $\mathrm{BOD}_{5}$ is satisfactory but its value in treated effluent exceeds the Standards of $250 \mathrm{mg} / \mathrm{l}$ and $100 \mathrm{mg} / \mathrm{l}$. Hence it is recommended to redesign the waste water treatment plant to achieve better performance, also based on results we can conclude that the secondary treatment system is not efficient to remove COD and BOD and hence it is to be redesigned.

\section{REFERENCES}

[1] A.S.Kolheand V.P.Pawar, "PHYSICO-CHEMICAL ANALYSIS OF EFFLUENTS FROM DAIRY INDUSTRY" Recent Research in Science and Technology,vol. 3(5): pages 29-32 (2011).

[2] Eaton, A.D.; Clesceri, L.S. and Grreenberg, A.E "Standard methods for the Examination of water and wastewater" $19^{\text {th }}$ edition (1995).

[3] Manual on water and waste water treatment, CPHEEO, Ministry of Urban Development, New Delhi, $4^{\text {th }}$ edition (1979).

[4] Metcalf and Eddy "Wastewater Engineering: Treatment and Reuse". Tata McGraw- Hill Edition, (2003).

[5] Pooja Sharma, "Performance Evaluation Of WWTP for Milk based Food Industry", ThaparUniversity,july (2008).

[6] Sushil Kumar Shah Teli "Perfromance evaluation of central wastewater treatment plant: a case study of Hetauda, Industrial District, Nepal", Environment and natural resources journal vol. 6, no. 2, pp-36-52 (2007). 